\title{
Participation of Related Undertakings in the Same Tendering Procedure: Is the Principle of Competition Infringed?
}

Penelope Alexia Giosa*

\author{
C 144/17 Lloyd's of London v Agenzia Regionale per la Protezione dell' Ambiente della \\ Calabria, ECLI:EU:C:2018:78.
}

\section{Introduction}

On February 8, 2018, the European Court of Justice (“ECJ") delivered its judgment on whether the principles of transparency, equal treatment and non-discrimination preclude national legislation which allows the simultaneous participation in the same tendering procedure of several syndicates of Lloyd's of London, whose tenders are signed by a single person. The case is interesting primarily because of its practical implications for contracting authorities that have an interest in excluding candidates or tenderers in case of potential intra-group collusion. In other words, this case will have an impact on the exposure of contracting authorities to bid rigging, which is a very deliberate breach of the law that involves the overpaying of tax payers' funds and raises prices artificially between 6 and 48 per cent above the competitive level. ${ }^{1}$ Additionally, the Lloyd's of London $v$ Arpacal judgment clarifies whether the participation of related undertakings in a common tendering procedure for the award of a public contract is a reason or not for their automatic exclusion from the call for tenders.

\section{Facts}

Calabria Regional Environmental Protection Agency, Italy (“Arpacal”) is an Italian environmental agency, whose main task is the natural protection of Calabria and the verification of environmental regulations. On 13 August 2015, Arpacal launched an open tendering procedure for the award of a contract for insurance cover services, with a view to covering risk linked to the agency's civil liability towards third parties and workers for the period covering the years 2016 to 2018. The public contract would be awarded on the basis of the most economically advantageous tender (MEAT) criterion, meaning on a price-quality basis that generally enables contracting authorities to ask from suppliers not only low prices but also technical requirements that ensure a specific standard of quality for the products/services procured.

\footnotetext{
* PhD candidate in Competition and Public Procurement Law, Centre for Competition Policy (“CCP”), University of East Anglia.

${ }^{1}$ Commission, Staff Working Paper accompanying the White Paper on Damages Actions for Breach of the EC Antitrust Rules, $\operatorname{COM}(2008) \quad 165$ final, http://eur-lex.europa.eu/legalcontent/EN/TXT/PDF/?uri=CELEX:52008SC0404\&from=EN (accessed 20 December 2018); J.B. Baker The Case for Antitrust Enforcement (2003) 17 Journal of Economic Perspectives, pp. 27, 29; Competition and Markets Authority Local Authorities and Competition, www.gov.uk/government/uploads/system/uploads/attachment_data/file/669668/local_authorities_and_ competition_final_report.pdf (accessed 27 Dec. 2017), p. 10; I. Apostolakis, Antitrust Liability in Cases of Indirect Contacts between Competitors: VM Remonts, (2017) 54 CMLR, 609.
} 
Lloyd's of London ("Lloyd's") is a leading insurance platform/market providing specialist insurance service to businesses, people and communities in more than 200 countries and territories. It is composed of insurance companies, limited partnerships, individuals and other entities, which group together and form specialist syndicates that underwrite insurance policies. ${ }^{2}$ Each syndicate maintains and staffs a physical office or stall on the premises of the Lloyd's Market at Lloyd's headquarters in London. ${ }^{3}$ Each syndicate is given a number by Lloyd's to identify them.

Upon Arpacal's call for tender on 13 August 2015, two Lloyd's syndicates, Arch Underwriting at Lloyd's Ltd and Tokio Marine Kiln Syndicates Limited, participated in the open tendering procedure by submitting their bids. Both bids were signed by the Special Agent of Lloyd's General Representative for Italy. In view of the fact that both bids were attributable to a single decision-making centre, Arpacal excluded the two syndicates from the procedure, in virtue of article $38(1)(\mathrm{m})$, quarter, of Legislative Decree No 163/2006. ${ }^{4}$ The Special Agent of Lloyd's General Representative for Italy challenged Arpacal's administrative decisions before the Regional Administrative Court of Calabria, Italy ("Regional Court") and as a result the Regional Court censured them and ordered the readmission of the two syndicates to the tendering procedure. Despite the Court's order, on 14 December 2016 Arpacal excluded again the two syndicates from the procedure on the same grounds. Still through its General Representative for Italy, Lloyd's brought fresh proceedings against Arpacal's decision before the Regional Court. Lloyd's argued that it is a collective legal person with multiple structures, which is composed of natural and legal persons that act independently within syndicates. ${ }^{5}$ Lloyd's syndicates are individual groups which operate independently from one another and in competition with one another even if they belong to the same organization. ${ }^{6}$ Moreover, none of the internal structures has autonomous legal personality but acts through the General Representative who, for each country, is the sole representative for all syndicates operating in that territory. The General Representative confines himself to transmitting on headed paper, without taking part in the decision-making process of each syndicate, the content of the model response to a call for tenders and standard forms completed and approved by each syndicate. ${ }^{7}$

\footnotetext{
${ }^{2}$ Lincoln Adventures, LLC v. Certain Underwriters of Lloyd's of London, 2017 U.S. Dist. LEXIS 136684 (D.N.J. Aug. 23, 2017).

3 ibid.

${ }^{4}$ Article $38(1)(\mathrm{m})$, quarter, of that legislative decree contemplated that tenders which are in relation to another participant in the same tendering procedure, in a situation of control for the purposes of article 2359 of the Codice Civile (Civil Code) or in any relationship, including a de facto relationship, where the situation of control or relationship means that the tenders are attributable to a single decisionmaking centre would be excluded from participation in a procedure for the award of concessions and of public works, supply and service contracts, and could not conclude contracts pertaining thereto or sub-contracts.

${ }^{5}$ Case C-144/17 Lloyd's of London v Agenzia Regionale per la Protezione dell' Ambiente della

Calabria ECLI:EU:C:2018:78, para. 17.

${ }^{6}$ ibid.

7 ibid, para. 43.
} 
On the other hand, Arpacal argued that there are several factors suggesting that tenders are attributable to a single decision-making centre. First of all, identical forms were used for submitting the tenders. ${ }^{8}$ Secondly, it was the same person, namely the Special Agent of the General Representative for Italy, who signed the tenders of both Lloyd's syndicates. ${ }^{9}$ Thirdly, the official stamps on both financial tenders were bearing consecutive numbers. ${ }^{10}$ Fourthly, the statements and declarations were identical in both tenders submitted by Lloyd's syndicates. ${ }^{11}$ For all these reasons, Arpacal - the relevant contracting authority- held that there was infringement of the principles of confidentiality of tenders, fair and free competition and equal treatment of tenderers, as the Special Agent of that Representative must have been aware of the content of the tenders submitted by Lloyd's syndicates.

The Regional Court upheld Lloyd's action through its General Representative for Italy, on the ground that the particular structure of Lloyd's operates in different countries through a single General Representative in accordance with United Kingdom rules and regulations. Likewise, the Supervisory Authority for Public Contracts in Italy opined that the independence of syndicates and competition between them serve to ensure free competition and the equal treatment of candidates. Therefore, it was held that there was no infringement either of Article 38(1)(m), quater, and (2) ${ }^{12}$ of Legislative Decree No 163/2006, or of the principles of competition, independence and the confidentiality of tenders. However, the Regional Court decided to stay the proceedings and ask the ECJ for a preliminary ruling, uncertain as it was about whether the principles of transparency, equal treatment and non-discrimination, which derive from articles 49 and 56 TFEU and are referred to in article 2 of Directive 2004/18, must be interpreted as precluding legislation of a Member State which does not allow two syndicates of Lloyd's to be excluded from participation in the same procedure for the award of a public service contract for insurance merely because their tenders were each signed by Lloyd's General Representative for that Member State. ${ }^{13}$

\footnotetext{
8 ibid, para. 18 .

${ }^{9}$ ibid.

10 ibid.

11 ibid.

${ }^{12}$ Article 38(2) of the Legislative Decree No 163/2006 contemplated that for the purposes of paragraph (1)(m) quater, the tenderer shall attach one of the following declarations: (a) a declaration that it is not in a situation of control for the purposes of Article 2359 of the Civil Code in relation to any person, and that it is submitting the tender independently; (b) a declaration that it is not aware of the participation in the procedure of persons that are, in relation to the tenderer, in any of the situations of control referred to in Article 2359 of the Civil Code, and that it is submitting the tender independently. In the situations described in points (a) and (b), the contracting authority shall exclude those tenderers in respect of which it establishes that the tenders are attributable to a single decision-making centre, on the basis of unambiguous evidence. Verification shall take place and any tenders be excluded after the opening of the envelopes containing the financial bid.

${ }^{13}$ Case C-144/17 Lloyd's of London v Agenzia Regionale per la Protezione dell' Ambiente della Calabria ECLI:EU:C:2018:78, para. 24.
} 


\section{Judgment}

Despite the fact that the new Directive 2014/24/EU on public procurement was adopted on 26 February 2014, i.e. before the tendering procedure at issue was launched on 13 August 2015, it is the old Directive 2004/18/EU on the coordination of procedures for the award of public works contracts, public supply contracts and public service contracts that applies ratione temporis to the main proceedings, as the time period for the transposition of the new Directive 2014/24/EU expired on 18 April 2016. Hence, according to the old Directive and specifically based on article 45 that specifies the grounds for the exclusion of an economic operator from participation in a tendering procedure, the membership of entities in the same organization does not constitute a ground for their exclusion in order to prevent any risk of collusion between them. This is so because the approach of the European legislator was to adopt only grounds for exclusion based on the objective findings of facts or conduct specific to the contractor concerned, such as to cast discredit on his professional reputation or call into question his economic or financial ability to complete the works covered by the public contract for which he is tendering. ${ }^{14}$ However, since the nature of the grounds for exclusion under article 45 of Directive 2004/18/EU is discretionary, there is always the possibility of Member States to maintain or establish in addition to those grounds for exclusion, substantive rules intended to ensure, as regards public contracts, observance of the principles of equal treatment of all tenderers and of transparency, provided that the principle of proportionality is observed. ${ }^{15}$ Based on this possibility, Italy adopted legislation such as that at issue, i.e. the Legislative Decree No 163/2006, in order to prevent any potential collusion between participants in the same procedure for the award of a public contract. Yet, in any case this legislation must not infringe the principle of proportionality by going beyond what is necessary to achieve the intended objective. ${ }^{16}$

By enabling the automatic exclusion of candidates or tenderers that are in a relationship of control or of association with other competitors, the ECJ held that the contracting authority goes beyond what is necessary to prevent collusive behaviour and to ensure the application of the principle of equal treatment and compliance with the obligation of transparency. ${ }^{17}$ Such an automatic exclusion would be an irrebuttable presumption of mutual interference in the respective tenders, for the same contract, of undertakings linked by a relationship of control or of association. ${ }^{18}$ This would also mean that the relevant candidates or tenderers would not be able to

\footnotetext{
14 Case C-213/07 Michaniki AE V Ethniko Simvoulio Radiotileorasis, Ipourgos Epikratias ECLI:EU:C:2008:731, para. 42.

${ }^{15}$ Case C-538/07 Assitur Srl v Camera di Commercio, Industria, Artigianato e Agricoltura di Milano ECLI:EU:C:2009:317, para. 21.

16 ibid, para. 23-24; Case C-376/08 Serrantoni Srl v Consorzio stabile edili Scrl ECLI:EU:C:2009:808, para. 33; Case C-425/14 Impresa Edilux Srl v Societa Italiana Costruzioni e Forniture Srl (SICEF) ECLI:EU:C:2015:721, para. 29.

${ }^{17}$ Case C-144/17 Lloyd's of London v Agenzia Regionale per la Protezione dell' Ambiente della Calabria ECLI:EU:C:2018:78, para. 35.

18 ibid, para. 36.
} 
produce evidence before the relevant contracting authority to show the opposite, namely that their tenders are independent. Further, the ECJ clarified that the automatic exclusion of candidates or tenderers and all that goes with it would prohibit the widest possible participation by tenderers in a call for tenders. ${ }^{19}$ Therefore, the mere fact that tenders such as those in the main proceedings have been signed by the same person, meaning the Special Agent of Lloyd's General Representative for Italy, cannot justify per se the automatic exclusion of Lloyd's syndicates from the tendering procedure at issue. ${ }^{20}$ Consequently, the principles of transparency, equal treatment and nondiscrimination do not preclude legislation of a Member State, which does not allow two syndicates of Lloyd's of London to be excluded from participation in the same procedure for the award of a public service contract for insurance merely because their respective tenders were each signed by the General Representative of Lloyd's of London for that Member State but instead allows their exclusion if there are unambiguous evidence that their tenders were not drawn up independently. ${ }^{21}$

\section{Comments}

The ECJ saw in the preliminary question submitted by the Regional Court a great opportunity to clarify that the systematic exclusion of bidders from procurement procedures merely because they are in a relationship of control or of association with other competitors should not narrow the market before assessing first the facts of each case. This ruling complies with the rationale of the old Directive 2004/18/EU, which does not contain any provision prohibiting in the first place the participation of related undertakings in a public procurement procedure. Likewise, the new Directive 2014/24/EU does not contemplate the exclusion of linked tenderers from the same public tender process, though it did go even further by adding an explicit competition ground for excluding competition law offenders from procurement process, emphasizing in this way the need to protect public markets from anticompetitive activities, such as bid rigging. ${ }^{22}$

The significance of such an ascertainment becomes particularly apparent in case of public markets with characteristics supporting collusion. It is likely that in such cases there will be a small number of companies remaining to deliver the public contract successfully. An illustrative example is the construction industry where 103 companies in the UK were found to have breached competition law in 2009 by getting

\footnotetext{
19 ibid; Case C-538/07 Assitur Srl v Camera di Commercio, Industria, Artigianato e Agricoltura di Milano ECLI:EU:C:2009:317, para. 29-30; Case C-376/08 Serrantoni Srl v Consorzio stabile edili Scrl ECLI:EU:C:2009:808, para. 39-40; Case C-425/14 Impresa Edilux Srl v Societa Italiana Costruzioni e Forniture Srl (SICEF) ECLI:EU:C:2015:721, para. 36.

${ }^{20}$ Case C-144/17 Lloyd's of London v Agenzia Regionale per la Protezione dell' Ambiente della Calabria ECLI:EU:C:2018:78, para. 39.

${ }^{21}$ ibid, para. 46.

${ }^{22}$ According to the new exclusion ground that was added in Article 57, para.4 (d) of the Directive 2014/24/EU, contracting authorities may exclude or may be required by Member States to exclude from participation in a procurement procedure any economic operator, where the contracting authority has sufficiently plausible indications to conclude that the economic operator has entered into agreements with other economic operators aimed at distorting competition.
} 
involved in cover pricing. ${ }^{23}$ In the relevant decision report, the Office of Fair Trading ("OFT") stated that if all infringers were excluded from tender lists, the public sector would struggle to find bidders to carry out the work, as cover pricing in the construction industry is a "widespread and endemic practice". ${ }^{24}$ Thus, if it were accepted that contracting authorities should be able to automatically exclude from procurement procedures bidders with a relationship of control or of association with other competitors regardless of their bids at issue, tender lists would become even shorter and this would be critical, as sometimes the relevant market turns out to be a monopoly. Of course this has always to do with the structure of the relevant market and it should be examined on a case by case basis.

The robustness of the present judgment was confirmed in May 2018 when the ECJ considered the Specializuotas Transportas, a Lithuanian case where linked tenderers submitted separate offers in the same public tender process for waste management services. ${ }^{25}$ It was held that when a contracting authority has evidence that calls into question the autonomous character of the tenders submitted by certain tenderers, it is obliged to examine all the relevant circumstances and request, where appropriate, additional information from those tenderers, whether their offers are in fact autonomous. ${ }^{26}$ This ruling is in line with the judgment at issue, as it presupposes the exclusion of the related tenderers only after the contracting authority assessed the evidence produced before it by the relevant tenderers. The only difference between these two cases is that in Specializuotas Transportas case the interrelation between the two tenderers was raised as an issue by another tenderer that did not manage to win the public award and not by the contracting authority as in Lloyd's of London $v$ Arpacal case. For this reason, the ECJ ruled that where evidence is produced before a contracting authority which challenges the autonomy of bids because they are submitted by related bidders, it has a duty to proactively investigate whether the offers made are autonomous and independent, requesting additional information from those bidders as appropriate.

Another really interesting point that the ECJ made in Specializuotas Transportas case regards the standard of proof which is required in order to determine that a tender is neither autonomous nor independent. It was held that a breach of the EU rules governing public procurement may be proved not only by direct evidence, but also through indicia, as long as they are objective and consistent and under the condition

\footnotetext{
${ }^{23}$ BBC "Building Companies fined $£ 129.5 \mathrm{~m} "<$ http://news.bbc.co.uk/1/hi/business $/ 8268116 . \mathrm{stm}>$ accessed on 20 December 2018.

${ }^{24}$ OFT "Competition Act 1998-Decision of OFT No.CA98/02/2009-Bid Rigging in the Construction $\begin{array}{lllll}\text { Industry in } & \text { England, } & \text { September } & 2009 \text { " }\end{array}$ http://webarchive.nationalarchives.gov.uk/20140402142426/http://www.oft.gov.uk/shared_oft/business leaflets/general/CE4327-04_Decision_public_1.pdf $>$ accessed on 20 December 2018.

${ }^{25}$ See Case C-531/16 Specializuotas Transportas, ECLI:EU:C:2017:883, where two of the tenderers in a public tender were subsidiaries of the same parent company sharing the same shareholder and management board directors.

${ }^{26}$ ibid, para. $27,33$.
} 
that the related tenderers are in a position to submit evidence in rebuttal. ${ }^{27}$ Based on this finding, it would be sufficient for Arpacal to use indications, such as the fact that each syndicate maintains and staffs a physical office or stall on the premises of the Lloyd's Market at Lloyd's headquarters in London, in order to prove that their tenders were not drawn up independently.

All in all, it could be said that Lloyd's of London $v$ Arpacal case puts some necessary restrictions to contracting authorities when it comes to the exclusion of related tenderers from the tendering procedure. In this way, it is underlined that the exclusion grounds in public procurement cannot be seen purely as an element of competition policy, but rather as a means of securing trust in government procurement.

27 ibid, para. 37. 